УДК 73.03

Oleksandr Honcharuk

Candidate of Art History

Associate Professor of the Monumental and

Decorative Sculpture Department of

Lviv National Academy of Arts

https://orcid.org/0000-0002-4516-9518

\section{A sculptural portrait in the work of Emmanuil Mysko: the evolution of plastic language}

\begin{abstract}
Анотація. Скульптурний портрет творчості Еммануїла Миська: еволюція пластичної мови. У статті осмислено особливості розвитку скульптурного портрета у творчості Еммануїла Миська. Визначено зміни, які відбуваються утворах майстра, де формується новий простір, у якому портретна скульптура стає об'єктом зберігання і передачі інформації. Доведено, що візуалізація сторінок української історії відбувається в основному через уособлення окремих подій у постатях видатних діячів свого часу. Проведено аналіз цілого ряду джерел, пов'язаних з особливостями художньо-критичного осмислення складних творчих процесів, характерних для творчості Еммануїла Миська.
\end{abstract}

Ключові слова: портрет, образ, скульптура, культура, художні особливості.

$\mathrm{H}$ istorical experience demonstrates the importance of creating a portrait sculpture of a contemporary. Its evolution and development show the changes of public significance, but do not lessen the needs of its existence in any case. The late 50s of the 20th century was a turning point for Western Ukrainian sculpture, which is mostly associated with the beginning of active creative work of the young generation of artists. They have a new understanding of plastic and figurative tasks, the tendency to in-depth psychological characteristics of the depicted models. Young sculptors tried to see something unique in a person; they were interested in his strong personality. In their first serious works, they demonstrate a new approach to national heritage and the processes that originated at the beginning of the 'thaw' in Ukrainian fine art at that time. The searches for an individual style can be seen in easel works. Emmanuil Mysko is a prominent representative of this period, in whose works the interest to an intimate portrait, to a perceptive image of a person in the entirety of his spiritual world is formed $[4 ; 6]$.

The editions of the last 1980s-1990s: catalogues of sole and collective exhibitions with prolusions, booklets, collections, almanacs and articles in periodic are of particular importance for the study of E. Mysko's portrait sculpture. In scientific researches by I. Holod [2], H. Holubets [3], N. Mits [7] and others [5; 8], the sculptor appear as personality with a vivid creative face, an individually unique master. However, the creative work of famous Lviv sculptor E. Mysko is not sufficiently studied.

Statement of basic materials. In the art of sculpture of the second half of the 20th century, the portrait of a contemporary takes on a special aesthetic significance, serves as a special path to a unique individuality, infinitely various inner world of a person. Its evolution appears as a history of the development of personality, his form of being in the society [8, p. 280-289]. The specificity of creative approaches is explained by the characteristics of portrait sculptures by E. Mysko.

The purpose of our study is to illuminate the creative work of E. Mysko, analyse the main tendencies of figurative and plastic solutions of the sculptor's oeuvre. Our task is to determine the character of traditions, show their significance in forming of artistic features of portrait sculpture of the master. The generation of the artists, to which E. Mysko belongs, set out on its artistic journey at the late 1950s and together with its teachers, artists of the elderly generation contributed to the development of Ukrainian art in the second half of the 20th century.

For E. Mysko, in his early portraits (P. Balla and F. Nirod, both of 1957; O. Kulchytska, 1957-1960), created in post-war period, the following things were important as: the artist is captured by spiritual state of a person, special creative environment, in 
which he is present. These portraits seem to fix a complicated way of understanding of a person character in its entirety and complexity. As in his most portraits performed in the following decades, E. Mysko concentrated his special attention on a person face; he strives to depict in his features a depth, the richness and complexity of the character of a depicted person $[4 ; 5]$.

In portrait sculpture of the People's artist of the USSR F. Nirod, a Swede by origin, E. Mysko created a bright figure of a famous artist of theatrical scene. During 1961-1989, F. Nirod ably arranged the performances as the art director of Taras Shevchenko Kyiv Opera and Ballet Theatre. He became the author of many stage designs, in particular, well-known Spartacus and Romeo and Juliet ballets that confirms a typical to him tendency to heroic and dramatic or figuratively scenic solution of the stage space. In the artist's portrait (tinted plaster, 1957), E. Mysko showed the strength of the talent and unordinary personality of the artist. The face of the portrayed is concentrated, thoughtful and self-absorbed look of his eyes with low-set eyebrows, his intense vivid forehead expressed his continuous search for ideas, original composition solutions. His image is added with curly hair on the head that completely correspond to creative potential of the famous artist.

Another message is common for the portrait of a well-known Ukrainian artist Olena Kulchytska (wood, toning). Emmanuil Mysko created the image of a famous master of graphics and decorative and applied arts, the People's artist of the USSR (1956), which can be definitely included to the gallery of the best psychological portraits of famous figures of culture and art of Ukraine. Olena Kulchytska is a deep and unordinary personality, the author of high artistic works, performed after the motifs of folk art, which had been already exhibited in the pre-war period at the exhibitions of folk crafts and modern art in Kraków, Prague, Stanisławów, Kolomyia and Lviv [3, p. 156]. Unique ability of the sculptor to catch a life-like portrait is wellknown; it has been proved here very successfully. Barely bowed head, high forehead, eyes lowered, discreet smile on her thin lips - this is the image, which remained in the memory of people, who were personally acquainted to O. Kulchytska. Her portrait image combines feminine tenderness, calmness and strong spirit of the artist at the same time, who left a great creative heritage to her people, which powerfully echoes with unordinary personality of the author - Emmanuil Mysko [4].

The approach to the embodiment of a contemporary's image testifies that portrait sculpture of Lviv of cultural processes of that time has a specific by its nature function, appears as the means of opening new truths about a person, shows new realities and borders of personality understanding. Creative achievements of the late 50s clearly demonstrate that the invention of new forms of person re-evaluation in the portrait art first of all depend on personality and talent of an artist [1].

At the turn of the 50-60s of the 20th century, the artistic tastes of E. Mysko's oeuvre were formed in the atmosphere full of intensive innovative experiments, searches for new means of artistic expression. At this time, in the Soviet art, in opposition to Stalin's socialist realism, socalled 'strict' style was established. It called for laconism of shapes free of excessive detail and naturalism, for author's interpretation and wide generalization of the phenomena of modernity and history. At this time, an accent from a sculpturestory was ultimately transferred to a sculptureimage, to the embodiment of the theme rethought and re-evaluated by the author. The main point was to reveal a personal attitude to the depicted life phenomena or facts, assertion through their interpretation of author's, public and aesthetic position. In other words, the subjective beginning of creativity was established that had to change fundamentally the figurative and plastic structure of the oeuvre.

The creative work of E. Mysko, whose personality was formed in optimistically eventful time of the 'Sixtiers', his intensive search for solving professional problems were realized at the level of careful selection of life material, as well as the means of his plastic and composition and spatial interpretation. The figurative and thematic range of the master's oeuvre is wide and captivating: he turned to history and modernity, preferred monumentally generalized or intimate, deeply lyric works. The heroes of his portraits, along with their search for a harmonic beginning, are often marked by the features of inner conflict, spiritual straggle. 
In the 70s, the process of forming of a bright creative self-being of E. Mysko continued, beginning at the turn of the 50-60s. One of the most typical became the portrait of Oleksa Novakivskyi. If in the mentioned portrait of O. Kulchytska, the sculptor deliberately limited himself in dynamics of plastic accents, in the bust of O. Novakivskyi, he gave a vivid advantage of expression, which is completely corresponds to the nature of the famous Lviv painter of the early 20th century. In fact, for E. Mysko this work was the first experience of a historic portrait. In the process, he used a large iconographic material - the artist's self-portraits and photographs. However, the creative heritage of the painter, uniquely bright and life-affirming, was the main source of his inspiration. It was this that determined the stylistic, figurative and emotional content of the work, which is seemed to accumulate a huge charge of creative energy [7].

The artist saw and understood each model in his own way, and that is why he strived to highlight the main in the portrait. For this purpose, he, actually, turns to one or the other image, to that thing, which has the highest value to his mind. Such approach of the artist was established in the works of the mature period and generally defined the original creative manner of the sculptor [4, p. 3-16].

In the 60s and 70s, E. Mysko's striving for a more emotional embodiment of the image was growing. His portraits have the features of an experienced master. These works are multifaceted and filled with a subtle gamut of emotions. The sculptor looks not only for acute characteristics in the expression of the face of the portrayed, but also in general composition and plastic solution, harmony of silhouette lines, delicate relation of the main masses and details.

One of the most important components of image and plastic expression of E. Mysko's portraits became a motif of motion. It is always strictly individual, because the sculptor finds it in the process of careful studying of the portrayed. This is the motives before the next step - an exceptional skill in transmitting facial expression. The portraits of L. Levytskyi, Vasyl Odrekhivskyi and V. Petrov are illustrative of this. The admiration of lively painting manner of modelling leads sometimes to a certain lightand-dark parcelling of the shape, typical for the stylistic of impressionism [7].

In the portraits of the second half of the 70s and 80 s, E. Mysko gave preference to more massive shapes, tense plastics of volumes. He became even more sensitive to the features of the inner world of the portrayed, felt him unmistakably, revealed the soul wealth of the chosen nature by the means of plastics. In every character, the artist finds those traits, which help to form a deep and unique idea of the person (the portraits of T. Narimanbekov (1976), R. Lubkivskyi (1977), T. Zalkaln (1977), V. Tseltner (1978), Y. Dzyndra (1984), O. Honchar (1984), R. Ivanychuk (1984), Y. Lysyk (1984), M. Petrenko (1985), P. Martinson (1986), P. Zholtovskyi (1986), Z. Flinta (1989), M. Fihol (1989), and others). Thus, in the portrait of T. Narimanbekov the hair strands are dynamically performed, the wrinkles on the forehead are put together, the narrowed eyes under the arches of massive eyebrows convey the tensity of spiritual state of the artist, the dramatic nature of his feelings. And in T. Zalkaln's portrait, balanced and calm rhythms are dominative; his spiritual energy does not pervade the image, but is concentrated in his eyes, in their intent, deep look. M. Petrenko is fixed as if in the moment of doubt, an instant flight of thought, an important decision; his look is sideward. The face of P. Zholtovskyi is concentrated, frontally directed. At the same time, the sculptor skilfully reproduces the characteristic ironic smile common to the prominent scientist and art historian, the author of fundamental researches on the history of Ukrainian art. The head of $\mathrm{M}$. Fihol is proudly raised, the strands of the hair lie on his shoulders, and his look is directed into the distance, as if the scientist is thinking over the fate of his native Carpathian land [6, p. 30-41]. The typical feature of the artist's creativity is that there is no great difference between the images of workers and intelligentsia. The author reveals the peasants and workers as intellectual and thinking people, with a subtle organization of the inner world.

Creative achievements of E. Mysko from the 60s to the first half of the 90s make up the most significant component, the basis of the portrait genre in Lviv sculpture. Among the pleiad of local artists, he was the one, who worked almost exclusively in portraiture; and this is here he gained the glory of an unsurpassed master. The 
manner of mature creative person is felt in the latter oeuvres of the artist - the second half of the 80 s and the 90s of the 20th century.

The beginning of 'thaw' caused noticeable changes in the art environment, in particular, in the methods of performance and creative approaches. There was no return to modernist movements of the first third of the 20th century expected in such situation, but the artists obtained the relative freedom, which they were able to take advantage of. Although the 'thaw' period was short, its main consequence, which can be hardly overestimated from today's perspective, was the establishment of the nonconformist movement. Later, in the years of 'stagnation', it was their creativity and often their principal civic position that formed a kind of parallel world, invisible layer, where brave search and experiments took place.

The processes of changes touched the spheres of sculpture and, in particular, portrait sculpture. Feeling the weakening of ideological control, the artists tried to move away as quickly as possible from the dogmas and stereotypes of socialist realism, get rid of deliberate narrating, naturalism, extra detail. In the processes of the portraiture, the accents were obviously shifted from external depictive factors to the inner world of the portrayed, to the desires to show spiritual beauty of a certain historical character or a common person, a contemporary.

With the beginning of the 'thaw', the figures of national beacons, distinguished workers of science, culture and art, legendary heroes of the liberation struggle were becoming more and more dominant in the portrait sculpture. The Soviet power did not manage to return this process in the years of 'stagnation' to the 'desired direction'. Even in official portraits of revolutionaries or participants of the Patriotic War (the Second World War was called likewise those times), a significant strengthening of spiritual and emotional beginning occurred. The greatest changes can be fixed in performance of the portraits of contemporaries. The creative potential of the 60 s and the mid-80s, preserved and multiplied by Lviv sculptors, became the basis for new transformations of the late 20th century, a fruitful basement for appearance of the new generation of the artists.

In the second half of the 80 s and the 90s, Emmanuil Mysko remained the unsurpassed master of the portrait sculpture. The portrait is not just the most favourite genre of the artist, 'it is the expression of his own thought and reflection of the environment, creating the image of a contemporary' [2, p. 4]. The extraordinary nature of creative thinking of the sculptor was reflected in the number of his unique and selfbeing works. In particular, the portrait sculpture of Mykola Bidniak (1997) is remarked with its original artistic language. The image of the artist of uneasy destiny, who having lost his hands during the war, continued drawing by his mouth, E. Mysko performed by intentionally enlarging of expressive plastic shapes. They symbolize the will strength, incredible capability of M. Bidniak. In his face oval, deep, slightly narrowed eyes, a massive nose, thin closed lips are distinguished. Massive eyebrow arches hold deep horizontal wrinkles on his forehead. The general image of the inspired artist is completed with a small beard and thick wavy hair. The artist's head is firmly and powerfully expressed on a long neck, as if on a pedestal. This compositional technique is associated to some extend with the fact that $M$. Bidniak creates and works without his hands. With rough and dynamic strokes, the sculptor gives to the face the traits of endurance, unconquerable will and powerful spiritual energy. This image is intended to inspire the viewer to believe that every person can overcome almost everything; nothing will prevent a strong personality to assert himself and conquer in complicated ups and downs of life [5].

E. Mysko displayed one more outstanding person - the portrait sculpture of Lviv artist Karlo Zvirynskyi (1998). The tense expression of modelling, virtuosity of performing plastic shapes, impalpable details of the image similarity of the portrayed are characteristic to this portrait. The author has managed to reproduce the psychological image of the prominent person, who had a significant role in preserving of Lviv postwar artistic environment. The sculptor is likely to feel the inner pulse of selfless work and life of K. Zvirynskyi, the essence of his character and his spiritual qualities. Kind touching eyes, hidden behind the massive eyeglasses, a big nose, thin and well defined lips, sharp contours of his chin with a small beard and evenly brushed hair on the back of the head - it seems that all the details are common to many people. But their proportions, 
compositional comparison are unique. The viewer, at the first sight, without difficulty recognizes the extraordinary figure of $\mathrm{K}$. Zvirynskyi. As in the previous work, the head of the portrayed proudly raises on the long neck as of on a pedestal. The sculptor has been able to create the image of the artist to be accessible, insightful, sensual and at the same time full of creative independence and inspiration.

In the gallery of E. Mysko's portrait sculptures of the 90s of the past century, the busts of political and public figures occupy a significant place. Among them is Mykhailo Kosiv (1998). The sculptor very successfully depicts the calm, but active character of the portrayed, gravity, reasonableness of his thought and word. On the low bust, his head is slightly turned to the right, his eyes are covered with big eyeglasses, a straight nose, small moustache above the lips and a characteristic dimple on the chin. Separate details such as evenly brushed sideward hair slightly hanging over his forehead have an important role. A shirt collar and a tie wrap around the neck that underlines the intelligence, high culture and education of the character. In his glance, which is known to his acquaintances, the artist shows the state of thinking, inspiration, faith in positive changes. The choice of such spiritual state is not accidental, because the deputy of the Verkhovna Rada of Ukraine of five convocations, M. Kosiv, had made a considerable contribution to establishing and developing of the young state in the sphere of culture, spirituality, religious and regional studies, full functioning of Ukrainian language and education, analysis of actual political issues [6].

High professional mastery, unique talent of E. Mysko revealed in monumental bust of the Patriarch of the Ukrainian Greek Catholic Church Josyf Slipyi (1998). He 'was a living embodiment of the fate of the Ukrainian church and our people of the 20th century... became the voice of a 'silent church' and its spiritual support, never forgetting those his countrymen, who continued to be punished in captivity' [9, p. 233]. The sculptor created a spiritual, great and dignified image of the Patriarch: his look is insightful and gentle at the same time, his eyes are wise, slightly narrowed, with small wrinkles around, thick eyebrows hang low over his eyes. His high forehead under rich wavy hair, a straight nose, thick curled moustache and neat sharp small beard.

On the shoulders of the portrayed are priestly vestments, on which tissue cloth - decorated or embroidered, with deep folds on the shoulders, is visible with light relief. On his chest, the attributes of patriarchal dignity - the cross, the holly pictures of Jesus and God's Mother and Child are placed on three symmetrically crossed chains. All mentioned attributes are crafted with love: the contours of the figures on the holly pictures, the clear features of their faces, the inscriptions framed with ornamental lines. Between the holly pictures, a massive double cross is successfully accented with a clearly marked finish. The special organic unity of spiritual and physical beauty of the portrayed makes this work great, full of inner strength, and forms the image of an invincible Ukrainian, a worthy spiritual mentor and a son of an offended but indomitable nation. The portrait is likely to remind that time sooner or later puts everything in its place, throws fake heroes off their pedestals and, on the contrary, rises high the truly great persons, the memory of whom does not disappear, but continues to live in books, films, works of art. Exactly like this, one of the symbolic figures is great Patriarch Josyf Slipyi.

Conclusion. An analysis of E. Mysko's portrait sculptures brings to the conclusion that the master had made a significant contribution to the processes, which took place in the Ukrainian art of the second half of the 20th century. The artist persistently looked for the ways of creating a bright, emotionally filled and holistic image of a contemporary. Taking into account the ideological dogmas and postulates, the path he chose, was not, surely, easy. Not only Lviv art environment, but the Ukrainian art as a whole was step by step becoming free of the excesses of socialist realism, primitivization of art processes and was transferring to the creative freedom of the period of 'thaw'. The artist's interest in the face of a person, who has experienced heroic achievements and tragic losses in the past, and now creates a new history, was not faded and constantly revealed by new creative facets. The portrait sculptures of Emmanuil Mysko are the significant component of the Ukrainian art of the second half of the 20th century.

1. Белічко Ю. В. Художник. Мистецтво. Час: 36 вибраних мистецтвознавчих статей. Київ : Мисте- 
цтво, 1982. 135 с.

2. Голод І. Еммануїл Мисько. Скульптура. Львів : Брати Сиротинські і К, 1999.58 с.

3. Голубець Г. В. Професійне декоративно-ужиткове мистецтво другої половини $\mathrm{XX}$ століття в музейних колекціях Львова. Львів : КолірПРО, 2015. 62 c.

4. Мисько Е. Виставка творів. Галерея ТОСХУ, 1995. Тернопіль : Лілея, 1995. 18 с.

5. Мисько Е. Мої друзі: виставка творів / автор-упорядник О. Пеленська. Львів, 1989. 12 с.

6. Мисько Е. Скульптура : альбом. Львів : Брати Сиротинські і К, 1999. 42 с.

7. Міц Н. В. Еммануїл Мисько : бібліографічний покажчик. Львів : Каменяр, 1996. 60 с.

8. Попова Л. И., Цельтнер. В. П. Очерки о художниках советской Украины. Москва : Советский художник, 1980. 390 с.

9. Проблема человека в западной философии / сост. и послесл. П. С. Гуревича ; общ. ред. Ю.Н. Попова. Москва : Прогресс, 1988. 552 с.

\section{References:}

1. Belichko, Y.(1982). Artist. Art. Time: 36 selected art historical articles. Kyiv : Mystetstvo [In Ukrainian].

2. Holod, I. (1999). Emmanuil Mysko. Sculpture. Lviv : Braty Syrotynski i K. [In Ukrainian].

3. Holubets, H. (2015). Professional decorative and applied arts of the second half of the 20th century in the museum collections of Lviv. Lviv : KolirPRO [In Ukrainian].

4. Mysko, E. (1995). Exhibition of works. Gallery of TOSKhU (TOCXY). Ternopil: Lileya [In Ukrainian].

5. Mysko, E. (1989). My friends: exhibition of works. O. Pelenska (Ed.). Lviv. [In Ukrainian].

6. Mysko, E. (1999). Sculpture: album. Lviv : Braty Syrotynski i K. [In Ukrainian].

7. Mits, N. (1996) Emmanuil Mysko: bibliographical index. Lviv: Kamenyar [In Ukrainian].

8. Popova, L. \& Tseltner, V. (1980). The outlines of the artists of Soviet Ukraine. Moskow: Soviet artist. [In Russian].

9. Popova, Y. (Eds.). (1988). The problem of a person in western philosophy. Moskow: Progress. [In Russian].

\section{ANNOTATION}

Oleksandr Honcharuk. A sculptural portrait in the work of Emmanuil Mysko: the evolution of plastic language. In this article a complex analysis of visual structural features in portraits series of representatives of Ukrainian intellectuals, which was created by E. Mysko. In particular, there were identi ed the speci city of visual interpretations and conceptual foundations of that series in view of professional and personal characteristics portrayed. Except that in this article have been made comparative analysis of the essential series, which displayed the unique character and features of Emmanuil Mysko's artistic style, his method of working with nature, and especially visual features of pictured characters which are called «living sculpture». Accordingly, the main focus was applied on the representation characteristics of formal-plastic solutions in the sculptures of artist Ivan Muzychko, I.Khoma, M. Labunka, W. Sternyuk, J. Slipyj. In addition, in this article individualized composition, forming and psychological accents, which was made by E. Mysko in each of these portraits have been noted.

Keywords: sculpture, gurative and plastic solutions, portrait series, structure of the artistic image, the Ukrainian intellectuals. 